complaint open to increasingly alert patients for which, or for whom, the onus of management in the code of practice is being placed on the nurse in charge of the ward and her record book.

I estimate that there are already 11 or 12 channels of complaint open to the customers. By all means let us establish machinery that allows free comment and honest answer, but let it be a system that will be effective in practice and one that does not unnecessarily overburden the ward staff.-I am, etc.,

C. GRIMSHAW

Henley-on-Thames

1 Report of the Committee on Hospital Complaints Procedure. London, H.M.S.O., 1973.

\section{Diagnosis of Rubella}

SIR,-Your recent leading article on this subject (16 February, p. 257) lists in considerable detail the clinical features of importance and states that the diagnosis of rubella can sometimes be made with ease, especially during epidemics. Though many would agree with this statement, we would like to stress that because rubella often presents atypically, or because infection which on clinical grounds closely resembles rubella may be caused by other viruses, tragedies still result from an over-confident clinical diagnosis in which undue emphasis is placed on the clinical features.

If during pregnancy a diagnosis of rubella is considered at all possible, however remotely, we feel that virological investigations must be carried out. Assessment is based on clinical data, including details of date, type, and duration of contact, as well as on serological studies employing haemagglutination inhibition and complement fixation tests and, if necessary, tests to detect rubella-specific IgM. ${ }^{2}$

Though your article states only that "arthralgia has been a feature in some epidemics of rubella," we feel that it is one of the few reliable clinical features in postpubertal females, since we have detected it in approximately $70 \%$ of nurses at St. Thomas's Hospital during both epidemic and non-epidemic times. The knees, fingers, and wrists are the most frequently affected joints.

In addition, undue reliance cannot always be placed on the detection of rubellaspecific IgM in a single serum sample. In our experience employing serum fractionation by sucrose density gradients, sera collected during the first week of illness may not always contain detectable virus-specific IgM despite the presence of adequate levels of haemagglutination-inhibiting antibodies. However, it will generally be present in a sample collected a few days later. Though rubella-specific IgM may be considered to be indicative of a recently acquired infection, failure to detect specific IgM in late convalescent sera may be due to quantitative factors. Thus if techniques of increased sensitivity are used (details of which will be published later) rubella-specific IgM can be detected for up to 14 months after both uncomplicated naturally acquired and vaccine-induced infections. Furthermore, when naturally immune persons are challenged they may develop not only serum IgG and IgA booster responses but also
IgM.

We were also impressed by Dr. Catherine Peckham's findings (16 February, p. 259) which showed that the administration of pooled human immunoglobulin may induce a subclinical infection which may not result in fetal damage. Might it now be worth conducting trials in which immunoglobulin obtained from recently convalescent patients with high antibody titres is given to those seronegative women who have been closely exposed to rubella, provided it can be administered within a very short time of first contact?-We are, etc.,

J. E. Banatvala JENNIFER M. BEST

W. AL-NAKIB

Department of Virology,

St. Thomas's Hospital and Medical School,

London S.E.1

1 Banatvala, J. E., Best, J. M., Bertrand, J., Bowern, N. A., and Hudson,'s. M., British Medical fournal, 1970, 3, 247. 2 Banatvala, J. E., Posgraduate Medical fournal,

\section{Rubella in Pregnancy}

SIR,-Dr. Catherine S. Peckham (16 February, p. 259) has confirmed that subclinical maternal rubella is far less likely to lead to congenital defects in offspring than clinical rubella.

From her previous work and in contrast to the Public Health Laboratory Service report $^{1}$ she also feels that specific immunoglobulin had and may still have a role in preventing clinical rubella during pregnancy. Accepting that immunoglobulin can mitigate rubella given clearly defined conditions, it is still very doubtful whether it could be really effective under the widely varying circumstances of everyday practice. On the other hand, Dr. Peckham reported that the defects in six children whose mothers had clinical rubella and immunoglobulin in the first trimester of pregnancy were mainly perceptive deafness. Possibly some specific antibody from the immunoglobulin reached the fetal circulation and had a limiting effect on viral multiplication in the fetal tissues, thereby preventing the more immediately apparent and severe cardiac or eye defects.

It should be clearly understood therefore that immunoglobulin should be offered only to women who understand and are prepared to accept the risk of having a baby with a congenital abnormality.-I am, etc.,

\section{Regional Virus Laboratory, City Hospital,}

1 Public Health Laboratory Service Working Party on Rubella, British Medical fournal, 1970, 2 ,

\section{E-rosette Inhibition Test of T-lymphocyte Sensitization}

SIR, - The rosette inhibition test, first described as an in vitro test of the potency of antilymphocyte serum (A.L.S.), ${ }^{1}$ is now widely used to monitor immunosuppression with various cytotoxic drugs in recipients of renal allografts. ${ }^{23}$ Under the conditions of the test the number of rosette-forming cells is less than 50 per 1,000 nucleated cells, ${ }^{3}$ and the exact identity of the central cells in the rosettes has until recently been a matter of debate. 5 It is now, however, generally accepted that these central cells are thymusdependent (T) lymphocytes. ${ }^{6-9} \quad$ E-rosette (Erythrocyte-rosette) formation occurs in a proportion of human lymphocytes $(65 \%$ in control subjects) with sheep red blood cells at low temperatures, and is now an acoepted characteristic of human T-lymphocytes. ${ }^{6-8}$

We have employed a test that makes use of the inhibition of E-rosettes by antithymocyte globulin (A.T.G.) in increasing concentrations. We have shown this to be a sensitive and highly reproducible test in the investigation of cell-mediated immunity in thyroid and related disorders. ${ }^{10}$ The methods for E- and EAC-rosette (Erythrocyte-Antibody-Complement-rosette) formation and the rosette inhibition test have been described eleswhere. ${ }^{8-10}$

The data shown in the figure are based on experiments employing mouse serum as a source of complement for EAC-rosette formation. ${ }^{11}$ The response curves of EACrosettes to A.T.G. were identical when mouse complement was replaced by human or guinea-pig complement, though different proportions of lymphocytes formed EACrosettes. The mean "inhibition concentration"-that is, that concentration of A.T.G.

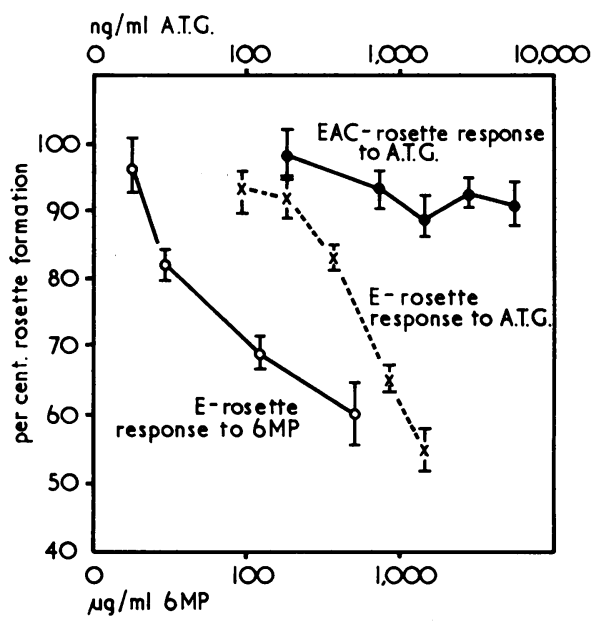

causing $25 \%$ inhibition of E-rosette formation-was $482 \pm 31$ (S.D.) $\mathrm{ng} / \mathrm{ml}$ in normal controls. However, when concentrations of A.T.G. up to $6,000 \mathrm{ng} / \mathrm{ml}$ were employed there was no significant reduction in EACrosettes. When 6-mercaptopurine (6 MP) was used (rather than A.T.G.) to inhibit E-rosette formation the mean inhibition concentration was $62 \pm 10.8 \mu \mathrm{g} / \mathrm{ml}$. The inhibition concentrations in Graves's and Hashimoto's diseases, reported elsewhere, were markedly elevated. 10

The test appears to have the advantage of directly measuring a T-lymphocyte function. Though the nature of the metabolic alterations produced by A.T.G. on T-lymphocytes to inhibit rosette formation is not clear, the end point of that effect indicates the "setting" (possibly the "degree" of sensitization) of a specific lymphocyte. ${ }^{10}$ Evidence favouring this assumption is provided by consistent increases in the amount of A.I.S. necessary to cause E-rosette inhibition during graft rejection following organ transplantation, ${ }^{2}{ }^{12}$ as well as other experimental evidence. 13

Contrary to the inhibitory effect on Erosette formation, A.T.G. in varying concentrations failed to cause significant inhibition of EAC-rosettes-that is, B-lymphocytes. It 
may be argued that the lymphocytes with complement receptors represent only a part of the total population of B-lymphocytes. ${ }^{14}$ However, the effect of A.T.G. was identical when either human complement or guineapig complement was used for EAC-rosette formation. With human complement the proportion of lymphocytes forming immune rosettes is significantly lower than with guinea-pig complement, suggesting that lymphocyte receptor for the two complements may not always be shared.

This work was supported by grants from the Medical Research Council of Canada (MT859). -We are, etc.,

NADIR R. FARID ROBERT E. MUNRO

VAS V. ROW ROBERT VOLPE

Endocrinology Research Laboratory,

The Wellesley Hospital,

Toronto, Ontario

1 Bach, J. F., and Antoine, B., Nature, 1968, 217, 2 Munro, A., et al., British Medical fournal, 1971,

3 Bewick, M., Ogg, C. S., Parsons, V., Snowdon, S. A., and Manuel, L., British Medical fournal, 1972, 3, 491.

4 Bach, J. F., and Dardenne, M., Transplantation Proceedings, 1972, 4, 345

5 Biozzi, G., Stiffel, C., Mouton, D., Bouthillier, Y., and Decreusefond,

6 Jondal $M$, $1972,4,339$. and Jondal, M., Holm, G., and Wigzell, H., fourn
of Experimental Medicine, 1972, 136, 207. 7 Yata, J., Tsukimoto, I., and Tachibana, $T$., 319.
Clical and Experimental Immunology, 1973, 14, 8 Farid, N. R., Munro, R. E., Row, V. V., and Volpe, R., New

Wybran, J., and Fudenberg, H. M., New England Fournal of Medicine, 1973, 288, 1072 .

o Fournal of Medicine, 1973, 288, 1072. V. V., and Volpe, R., New England fournal of Medicine, 1973, 289,' 1111.

11 Bianco, C., Patrick, R., and Nussenzweig, V., Fournal of Experimental Medicine, 1970, 132, 702. 12 Hamburger, J., Proceedings of the Royal Society

13 Raff, M. C., and Owen, J. J. T., in Advances in Experimental Medicine and Biology Vol. 12, p. 11, ed. K. Lindahl-Kiessling, G. Alm, and M. C.

\section{Rosette Inhibition Test and Cell-mediated Immunity}

SIR,-Dr. Helen M. Chapel and Dr. J. R. Batchelor (17 November, p. 385), reporting the results obtained with the rosette inhibition test carried out on lymphocytes from patients with severe burns, have shown that the minimum inhibitory concentration (M.I.C.) of antilymphocyte globulin is not related to the immunosuppression which follows a severe burn but to the ratio of sodium to potassium excreted in the urine. They conclude that the test is not a direct measure of cell-mediated immunological reactivity and may be affected by other factors, such as the increased production of adrenal steroids which is known to occur in this condition.

Since this test has been successfully used to monitor the degree of immunosuppression and to predict allograft rejection in transplanted patients, ${ }^{1-3}$ the point raised by the authors deserves funther consideration. We have used the test to follow the progress of 28 patients who had received a renal allograft, making two or three determinations per week from the day of transplantation for at least two months. Munro's method' with the modification introduced by Jondal ${ }^{4}$ to increase the number of rosettes, was used. The M.I.C. was significantly increased in 26 out of 27 seperate determinations made two to five days before rejection became clinically evident and in only 21 out of 260 determinations after which no clinical evidence of rejection developed. ${ }^{5}$

In order to check the possibility of interference with the rosette inhibition test by factors that can affect the urinary sodium: potassium ratio we have studied 12 patients, all receiving prednisone and azathioprine treatment, in whom there had been an immediate resumption of urinary flow after transplantation. No correlation was found between variations in the M.I.C. and in the urinary sodium: potassium ratio $(r=0 \cdot 11$, $\mathrm{n}=130, \mathrm{P}>0 \cdot 1)$. These findings support the view that the test can be successfully applied to predict renal allograft rejection which, as is well known, is mediated by cellular immunity.

The difference between our findings and those reported by Drs. Chapel and Batchelor may perhaps be explained by the differences in the method used. The modification introduced by Jondal, ${ }^{4}$ which permits highly accurate marking of the $\mathrm{T}$-cells, has been used also by Farid et al. ${ }^{6}$ who showed a close correlation between the MIC of antilymphocyte globulin and lymphocyte sensitization to thyroid antigens in Graves's disease and Hashimoto's thyroiditis. This suggests that the variation in the proportion of marked $T$ cells may be critical.-We are, etc.

\section{A. Cantaluppi}

Istituto di Patologia Medica

\section{G. FIORELLI}

Istituto di Urologia,

C. Ponticelli

Sezione di Nefropatologia,

Universita di Milano,

Milan, Italy

1 Munro, A., et al., British Medical fournal, 1971,

3, 271. P. A., et al., British Medical fournal,
Cullum, $1972,2,71$.

3 Bewick, M., Ogg, C. S., Parsons, V., Snowdon, S. A., and Manuel, L., British Medical fournal, $1972,3,49$

4 Jondal, M., Holm, G., and Wigzell, H., fournal of Experimental Medicine, 1972, 1936, 207.

5 Fiorelli, G., et al., Communication to the 6th Congress of the Organ Transplantation Society, Varese, 12-15 September 1973 Volpe, R., New England fournal of Medicine, 1973, 289, 1111 .

\section{Thyopac-5 Test}

SIR,-The practice of modifying serum thyroxine values to allow for variations in thyroxine-binding protein concentrations is well established. 1 We have compared the diagnostic accuracy of a new Radiochemical Centre kit (Thyopac-5), which provides a
6 Farid, N. R., Munro, R. E., Row, Vas V., and

means of determining both a serum thyroxine concentration and a normalized thyroxine ratio ${ }^{2}$ with those of other widely used tests. The tests considered were: in vivo-1 ${ }^{131}$ I neck uptakes (2-hour and 24hour), ${ }^{131}$ I neck uptake: thigh ratios (2-hour and 24-hour); in vitro - serum proteinbound iodine, serum thyroxine (Thyopac-4, Thyopac-5), triiodothyronine binding capacity (Thyopac-3), normalized thyroxine ratio (E.T.R. (Mallinckrodt), Thyopac-5), free throxine index (Thyopac-4 value $\times 100 /$ Thyopac-3 value).

Tests were performed on 300 patients (242 female and 58 male) ranging in age from 2 days to 84 years. Ninety-six investigations were performed using the Thyopac- 5 test and over 200 by each of the other methods. Follow-up information regarding the patients showed $35(11.7 \%)$ to be hypothyroid, $165(55.0 \%)$ euthyroid, and $92(30.7 \%)$ hyperthyroid, with eight remaining equivocal. The percentages of patients correctly differentiated by each method at the hypothyroid-euthyroid and hyperthyroideuthyroid borders are given in the table. Patients who were pregnant, taking a drug known to affect any of the tests, aged less than one year, or who had been previously treated for thyrotoxicosis with radioiodine were excluded from the selected group. The two normalized thyroxine ratio kits were of equivalent reliability, their test values being related by the equation: Thyopac-5 value $=0.65$ (E.T.R. value) +0.39 .

All the tests, with the exception of the 24-hour 131I neck uptake: thigh ratio, were more reliable for the diagnosis of hyperthyroidism than for hypothyroidism. Of the in vitro methods the normalized thyroxine ratio tests were the most reliable and the least affected by abnormal serum protein levels. The diagnostic accuracies of these tests were comparable with that of the best in vivo test, the 24-hour ${ }^{131}$ I neck uptake. The in vitro tests offer the advantage of greater convenience to both hospital staff and patients and do not involve the administration of radioisotopes to the patients. We have demonstrated the usefulness of the normalized thyroxine ratio tests and found the additional serum thyroxine figure available as part of the Thyopac- 5 test to be a valuable feature of the kit.-We are, etc.,

J. G. HARDY

Regional Radiotherapy Centre,

G. M. NEWBLE

Essex County Hospital

1 Clark, F., and Horn, $D_{25}$ B., fournal of Clinical Endocrinology, 1965, 25, 39. Ashkar, F. S., and Bezjian, A. A., Fournal of the
American Medical Association, 1972, 221, 1483.

\begin{tabular}{|c|c|c|c|c|c|}
\hline \multirow{3}{*}{ Test } & & \multicolumn{4}{|c|}{ Patients Correctly Diagnosed (\%) } \\
\hline & & \multicolumn{2}{|c|}{$\begin{array}{l}\text { Hypothyroid- } \\
\text { euthyroid Border }\end{array}$} & \multicolumn{2}{|c|}{$\begin{array}{l}\text { Hyperthyroid- } \\
\text { euthyroid Border }\end{array}$} \\
\hline & & $\begin{array}{c}\text { All } \\
\text { patients }\end{array}$ & $\begin{array}{l}\text { Selected } \\
\text { patients }\end{array}$ & $\begin{array}{c}\text { All } \\
\text { patients }\end{array}$ & $\begin{array}{l}\text { Selected } \\
\text { patients }\end{array}$ \\
\hline $\begin{array}{ll}\text { 2-hour }{ }^{131} \text { II neck uptake } & \ldots \\
\text { 24-hour }{ }^{131} \text { I neck uptake } & . \\
\text { 2-hour }{ }^{131} \text { neck uptake: } \\
\text { thigh ratio } \\
\text { 24-hour }{ }^{131} \text { I neck uptake: } \\
\text { thigh ratio } \\
\text { Serum protein-bound iodine } \\
\text { Serum thyroxine } \\
\text { Triodothyronine binding capacity } \\
\text { Thormalized thyroxine ratio } \\
\text { Free thyroxine index .. }\end{array}$ & $\begin{array}{ll}\because & \cdots \\
\cdots & \cdots \\
\cdots & \cdots \\
\therefore & \cdots \\
\cdots & \cdots \\
\cdots & \cdots \\
\therefore & \cdots\end{array}$ & $\begin{array}{l}76 \\
80 \\
70 \\
73 \\
76 \\
70 \\
68 \\
78 \\
66\end{array}$ & $\begin{array}{l}76 \\
82 \\
73 \\
76 \\
77 \\
70 \\
70 \\
83 \\
67\end{array}$ & $\begin{array}{l}91 \\
90 \\
88 \\
* \\
88 \\
86 \\
84 \\
91 \\
89\end{array}$ & $\begin{array}{l}92 \\
94 \\
91 \\
* \\
91 \\
89 \\
90 \\
92 \\
93\end{array}$ \\
\hline
\end{tabular}

*The 24-hour ${ }^{131}$ I neck uptake: thigh ratio was of no diagnostic value at this border. 